Western Washington University

Western CEDAR

\title{
Election Systems and Voter Turnout: Experiments in the United States
}

Todd Donovan

Western Washington University, todd.donovan@wwu.edu

Shaun Bowler

David Brockington

Follow this and additional works at: https://cedar.wwu.edu/politicalscience_facpubs

Part of the Political Science Commons

\section{Recommended Citation}

Donovan, Todd; Bowler, Shaun; and Brockington, David, "Election Systems and Voter Turnout: Experiments in the United States" (2001). Political Science Faculty Publications. 12.

https://cedar.wwu.edu/politicalscience_facpubs/12 


\section{CAMBRIDGE UNIVERSITY PRESS}

\section{Southern Political Science Association}

Election Systems and Voter Turnout: Experiments in the United States Author(s): Shaun Bowler, David Brockington and Todd Donovan Source: The Journal of Politics, Vol. 63, No. 3 (Aug., 2001), pp. 902-915

Published by: Cambridge University Press on behalf of the Southern Political Science Association Stable URL: http://www.jstor.org/stable/2691719

Accessed: $23 / 10 / 201417: 12$

Your use of the JSTOR archive indicates your acceptance of the Terms \& Conditions of Use, available at http://www.jstor.org/page/info/about/policies/terms.jsp

JSTOR is a not-for-profit service that helps scholars, researchers, and students discover, use, and build upon a wide range of content in a trusted digital archive. We use information technology and tools to increase productivity and facilitate new forms of scholarship. For more information about JSTOR, please contact support@jstor.org. 


\title{
Election Systems and Voter Turnout: Experiments in the United States
}

\author{
Shaun Bowler \\ University of California, Riverside \\ David Brockington \\ Universiteit Twente \\ Todd Donovan \\ Western Washington University
}

Theory suggests that majoritarian/plurality elections depress voter participation and that proportional election systems encourage greater voter mobilization and turnout. We examine the effect that cumulative voting (CV) has on turnout in local elections in the U.S. Variation in social/cultural context is largely held constant by our design while election system varies, allowing us to identify the unique effect $\mathrm{CV}$ has on turnout. We test if turnout is higher when CV is used in the same context as plurality rules. Consistent with expectations about institutional effects, turnout is about 5 percentage points higher under $\mathrm{CV}$ than in similar plurality elections.

\section{H} ow much do political institutions affect levels of voter participation? Typically, this question has been addressed by predicting turnout in the major industrialized countries with models that include measures of electoral rules (Jackman 1987; Jackman and Miller 1995; Powell 1986). Within these studies, the U.S. stands out as a case of exceptionally low turnout. This has generated varying degrees of concern. For some, low or declining levels of turnout are lamentable but not seen as a dramatic threat to democratic processes (Berelson, Lazarsfeld, and McPhee 1954; Polsby 1963). Others, however, believe that low turnout endangers the very legitimacy or fairness of American elections (e.g., Amy 1993; Lijphart 1997; Piven and Cloward 1988; Teixeira 1992).

There are at least two broad, complementary explanations for low participation in the U.S. Individual-level (behavioral) explanations emphasize characteristics correlated with participation and suggest that a sizeable proportion of the

Early versions of this paper were presented at the 1997 American Political Science Association and 1997 Pacific Northwest Political Science Association meetings. The authors thank Beth Cotrell and Tracy Sulkin for assistance and the WWU Bureau for Faculty Research for partial funding. Direct correspondence to donovan@cc.wwu.edu 
electorate lack qualities that might cause them to vote (e.g., Abramson and Aldrich 1982; Leighley and Nagler 1992; Verba and Nie 1972; Wolfinger and Rosenstone 1980). A second category stresses the effects that registration barriers, weak parties, and other rules have on depressing turnout (e.g., Alford and Lee 1968; Caldeira, Patterson and Markko 1985; Jackson, Brown, and Wright 1998; Nagler 1991; Rosenstone and Hansen 1993; Rosenstone and Wolfinger 1978; Rusk 1970).

Our study expands on these explanations by testing if semi-proportional elections are associated with higher turnout when used in the U.S. A number of cross-national studies have found that proportional representation (PR) elections are associated with higher turnout than plurality elections (Blais and Carty 1990; Blais and Dobrzynska 1998; Jackman 1987; Jackman and Miller 1995; Powell 1986). These important studies leave room for further tests of this effect. First, there are too few degrees of freedom to control for many of the place-specific factors that co-vary with plurality rules in cross-national settings. For example, the Powell and Jackman studies use cases that share historical, social, or cultural traits that co-vary with relevant electoral arrangements. ${ }^{1}$ This is problematic since one explanation of different rates of turnout is that nations have distinctive "political cultures" that affect their citizens" "subjective orientation to politics" (Verba 1965, 513). Important questions of research design must be addressed in order to demonstrate more conclusively that electoral systems, rather than place-specific factors such as culture, affect turnout. Second, cross-national studies cannot tell us what would happen to participation if a U.S. jurisdiction adopted PR.

What would be ideal, then, is the presence of variation in electoral rules within the same social and cultural context. Current experiments with local elections in the U.S. provide us with such a setting. ${ }^{2}$ Moreover, they also provide an opportunity to employ a quasi-experimental research design with a large number of cases. We test if turnout is higher in U.S. jurisdictions that use cumulative voting (CV), a semi-proportional election system, than in jurisdictions using plurality rules. Our research design is structured so that we control for place-specific factors that may confound the impact of electoral system rules. We do this by combining a quasi-experimental case selection with crosssectional and longitudinal statistical analysis of turnout.

Although nearly all federal, state, and local elections are contested under plurality rules, after the late 1980s numerous U.S. local jurisdictions began experimenting with CV. CV combines multimember districts with a semi-

\footnotetext{
${ }^{1}$ For example, plurality SMDs are found in the English-speaking U.S., UK, and commonwealth states ( 5 of the 19 cases, with an average turnout of $72.4 \%$ between 1971 and 1980). PR is present in Scandinavian states ( 5 of the 19 cases, with a turnout of $83.4 \%$ for this period).

${ }^{2}$ We "control" for the large variation in American cultural context, in part, by comparing many jurisdictions within the same states.
} 
proportional $^{3}$ translation of votes to seats and lowers the proportion of votes required to win a seat (Engstrom, Taebel and Cole 1989; Still 1984). At present, about 80 jurisdictions (cities, counties, and school districts) have adopted CV, with most concentrated in a handful of Southern states ${ }^{4}$ (Brischetto and Engstrom 1997; Cole and Taebel 1992; Cole, Taebel, and Engstrom 1990; Engstrom and Barrilleaux 1991; Pildes and Donoghue 1995).

$\mathrm{CV}$ was adopted on a case-by-case basis locally in response to actual or threatened actions under Section 2 of the Voting Rights Act (VRA). In the vast majority of cases where plaintiffs bring VRA challenges against local election rules, the remedy (reached by consent or by court order) is single-member districting (SMD). However, in a small number of cases, plaintiffs and defendants (local jurisdictions) have agreed to use $\mathrm{CV}^{5}$ There is no single reason why some places adopted CV rather than SMD as a remedy, but contributing factors include the preferences of individual attorneys handling the plaintiffs' cases, differences between defendants and plaintiffs over potential districting plans, and local minority-group leaders' willingness to use an experimental system (see Pildes and Donoghue 1995; Taebel, Engstrom and Cole 1988). CV also avoids those difficulties associated with using districts in small communities. ${ }^{6}$

\section{Mobilizing Effects of CV Elections}

CV elections could have the same effects on turnout as PR by eliminating the disincentives that plurality rules have on turnout. One probable disincentive for voters in plurality jurisdictions is that some perceive that their votes will be wasted. CV, like PR, allows voters from smaller (if not more) groups the possibility of voting for a winning candidate. CV could also increase voting by raising individual-level political efficacy, particularly among supporters of minority candidates. Cross-national opinion studies illustrate that citizens in PR nations are more satisfied with democracy (Anderson and Guillory 1997), and a panel study of the effects of changing from plurality to PR rules in New Zealand found that minor party supporters demonstrated significant increases in efficacy after the nation's first PR election (Banducci, Donovan, and Karp 1999).

\footnotetext{
${ }^{3} \mathrm{CV}$ does not have rules that allocate seats proportionately to votes. Rather, it reduces the likelihood that a plurality group will win all seats, particularly as district magnitude increases.

${ }^{4}$ Nearly all of the CV jurisdictions in this analysis are found in Texas and Alabama. There is one CV jurisdiction each in these data from New Mexico and Illinois.

${ }^{5}$ In a number of Texas cases, plaintiffs included the League of United Latin American Citizens (LULAC). In Alabama, they included a black political group, the Alabama Democratic Conference (ADC). Attorneys working for these groups filed cases on behalf of individuals with standing in various communities. LULAC and the ADC in particular each had attorneys who worked to promote semi-PR systems. Local plaintiffs working with different attorneys may have been much less likely to adopt CV. These attorneys' ability to "sell" CV to a local group was one factor affecting if it would be considered for adoption.

${ }^{6}$ These include dividing a small population into at least five districts and lowering the candidate pool in very small districts. We thank an anonymous reviewer for noting this.
} 
Voters in noncompetitive races can also realize the futility of voting (Amy 1993; Cox and Munger 1989; Guinier 1994, 94-97), and CV elections may be more competitive than plurality elections. For example, SMDs drawn with a majority concentration of any one group could discourage minority candidates from seeking office since they would have a poor chance of winning. ${ }^{7}$ Fewer candidates, moreover, might reduce the mobilizing effects of campaigns in plurality jurisdictions. ${ }^{8}$ At-large, "first past the post" rules that allow a majority group to sweep all seats (Engstrom and McDonald 1981; Taebel 1978) can have the same effects by discouraging minority candidates from contesting races. But with a lower proportion of votes required to win a seat, CV systems could increase the incentives for candidates to seek office. Cox (1999) has theorized that elites respond to such electoral competitiveness by trying to mobilize more voters.

Recent scholarship presents theoretical and empirical reasons for expecting an increase in voter mobilization efforts under PR (Canon 1999, 357; Cox 1999), and by extension, semi-PR systems such as CV. One key link between election system and turnout, according to Cox, are variations in the mobilization incentives that systems create for elites (Cox 1999, 411; see also Ladner and Milner 1999, 248). Lower thresholds of exclusion mean more candidates from nonplurality groups might seek office. Furthermore, unlike majority-minority SMDs, if the minority share of the participating electorate falls below the threshold of exclusion, minority candidates are not likely to win seats under CV (Brischetto and Engstrom 1997). As noted of CV in Texas, it requires "lots of shoe leather" for a candidate to be elected. "If there is not sufficient local mobilization to get out the minority vote. . the minority candidate is not likely to win" (Brischetto $1995,8){ }^{9}$

\section{Research Design and Methods}

Data on turnout in local elections were requested from the largest jurisdictions in the United States that employed CV. We sought data from all CV places having a 1990 population over 1,000 persons $(n=44)$. Each place adopted CV in response to conflict over limited (or nonexistent) representation of minori-

\footnotetext{
${ }^{7}$ This would be even more certain if we assume that voting is polarized along racial and ethnic lines, as is typically the case in places with VRA actions.

${ }^{8}$ Compared to SMD, multimember district elections of any type may be more competitive since when the number of candidates $(c)>$ the number of seats $(s)$, then a minimum of $s+1$ candidates are competing against each other for office. Under CV in the U.S., s is always 3 or greater, so a minimum of $\mathrm{c}=4$ can produce a contest where all 4 might campaign. Under SMD, if $\mathrm{s}=3$ and $\mathrm{c}$ is 4 , it is possible that only 2 compete against each other, while 2 others run uncontested.

${ }^{9}$ In Atlanta, Texas, for example, African Americans organized get-out-the-vote drives in AfricanAmerican communities to elect a candidate under CV. In several CV towns with Latino communities, the Southwest Voter Registration Education Project trained activists for local voter mobilization strategies. In another Texas town, a group called Concerned Citizens for Voting began mobilizing voters under the first CV election (Brischetto 1995, 9).
} 
ties, and all have sizable minority populations. We received turnout data from 28 (or $64 \%$ ) CV places.

Data also were obtained from communities using plurality elections. This set of cases was selected so that each plurality jurisdiction closely matched a specific CV place in key geographic and social characteristics. The 1990 U.S. Census allowed us to identify community-level measures of race and ethnicity, population size, percentage of residents having a high school degree, and median income. ${ }^{10}$ Each CV place was matched with a plurality place that was similar on each trait. For example, Rockford, Illinois (1990 pop. 139,426; 16\% African American, median income $\$ 28,282$ ) is the plurality jurisdiction matched with the CV city of Peoria, Illinois (1990 pop. 113,504; 21\% African American, median income $\$ 26,074$ ). In the end, we obtained turnout data for 21 of the 28 plurality jurisdictions matched with the $\mathrm{CV}$ places from which we received data.

These matched cases supply a control group of plurality places having demographic factors highly similar to the CV places. Each control city is located in the same state and generally in the same county as the "experimental" CV city with which it was matched. If CV school districts or counties were being matched with control cases, then similar in-state jurisdictions were identified in close proximity to the experimental places. ${ }^{11}$

Between 1997 and 1999, local officials in the experimental and control places were contacted by telephone and mail to obtain turnout data from recent elections. Officials in CV places were asked to supply data from their elections held under CV and from their final three plurality elections. This allowed us to conduct a longitudinal analysis of change in turnout within the set of "experimental" communities (pre- and post-adoption of $\mathrm{CV}$ ), in addition to the crosssectional analysis of differences in turnout between the experimental (CV) cases and the control (plurality) cases. Overall, 49 different jurisdictions (28 CV and 21 plurality) supplied turnout data on 215 elections. ${ }^{12}$ Table 1 reports mean turnout levels for each group of cases and reports means for key independent variables. Cases represent a jurisdiction's election in a specific year. ${ }^{13}$ Apart

\footnotetext{
${ }^{10}$ Demographic data were drawn either from the 1990 U.S. Census, or, in the case of school districts, from the School District Data Book on CD-ROM published by the U.S. Department of Education.

${ }^{11}$ The vast majority of elections follow the municipal model of holding elections in off-year and in odd months. For example, all Texas city council and school elections included in this analysis are held in early May of each year. Guin, Alabama, which does hold its elections every four years corresponding with presidential elections, does so in August, not November. There are no elections in this analysis that correspond with a national or statewide general election. The practical implication of this is that there are no national or statewide influences on turnout in these data.

${ }^{12}$ Most jurisdictions would provide information on turnout from recent elections. Refusals were greater when data from older elections were requested. Thus, from some places, we have longer time series than others. The majority of these jurisdictions stagger the election of seats, with elections for three or four seats held annually or every two years in many places.

${ }^{13}$ For example, case 1 election $_{\mathrm{ij}}$, where ${ }_{\mathrm{i}}$ is an individual election year and ${ }_{\mathrm{j}}$ is the jurisdiction.
} 
TABLE 1

Descriptive Characteristics: All Cases, Control, and Experimental Groups

\begin{tabular}{lcccc}
\hline & $\begin{array}{c}\text { All } \\
\text { Elections }\end{array}$ & $\begin{array}{c}\text { Continuous } \\
\text { Plurality } \\
\text { Elections } \\
\text { (Control) }\end{array}$ & $\begin{array}{c}\text { Plurality } \\
\text { Elections } \\
\text { Prior to CV } \\
\text { (Exp Pre) }\end{array}$ & $\begin{array}{c}\text { CV Elections } \\
\text { after Switch } \\
\text { from Plurality } \\
\text { (Exp Post) }\end{array}$ \\
\hline Turnout \% & $19(14)$ & $17(16)$ & $18(12)$ & $23(13)$ \\
Minority \% & $38(14)$ & $38(14)$ & $37(14)$ & $38(16)$ \\
High School Education \% & $56(10)$ & $56(09)$ & $55(10)$ & $55(11)$ \\
Median Income \$ & 19,756 & 21,210 & 18,807 & 19,263 \\
Total Number of Elections & $(3877)$ & $(3910)$ & $(3308)$ & $(3989)$ \\
\hline
\end{tabular}

Note: Main entries are means, standard deviations in parentheses. Control groups: Places using plurality elections continuously, matched with demographic and geographic traits of CV places. Experimental pre: Places using plurality contests prior to using new CV system. Experimental post: $\mathrm{CV}$ places after switching from plurality.

from slight variations in median income, the jurisdictions in each group are nearly identical. Our control group (from the matched places) includes results from 72 plurality elections. ${ }^{14}$ We also have turnout data for 74 at-large elections held in CV places prior to their adopting CV and 69 subsequent CV elections from those places.

The plurality (control) cases had slightly lower but statistically insignificant differences in mean turnout levels when compared to plurality elections held in the experimental (CV) places. Previous to their adoption of CV, our experimental communities averaged $17.9 \%$ turnout, which is comparable to $17.1 \%$ turnout for other plurality jurisdictions in our study. In keeping with expectations about the effects of semi-PR rules on participation, turnout was $5.6 \%$ higher $(23.5 \%)$ in the experimental cases after their adoption of CV. An ANOVA test determined that there are significant differences in turnout between these three categories $(F(2,212)=3.85, p=.02)$. A dependent samples t-test of the difference between mean turnout levels in the experimental places before and after changing to $\mathrm{CV}$ indicates a significant difference $(\mathrm{t}=2.91, \mathrm{p}=.005)$. There is no significant difference between the control and pre-experimental groups.

\section{Hypotheses and Model Specification}

We estimate cross-sectional regression models of turnout across all places (control, experimental pre-CV, and experimental post-CV) as well as longitudi-

\footnotetext{
${ }^{14} 54$ of these were conducted under at-large rules, while 18 were conducted under districted elections.
} 
nal models focusing on places experimenting with CV. Our discussion suggested several testable hypotheses. Clearly, if semi-PR election rules increase elite incentives to mobilize voters, make contests more competitive, or increase voter efficacy, then turnout should be higher under CV. Although we cannot specify the actual mechanism that operates in $\mathrm{CV}$ elections to affect turnout, we can isolate the general effect of election rules in a regression equation by using a dummy variable, where $1=$ a CV election, and $0=$ a plurality election. The coefficient for this term represents the difference in turnout between plurality and $\mathrm{CV}$ elections.

Given the controls built into our research design, we can be rather confident that this dummy variable captures differences that stem from election rules. However, since we anticipate that communities with a larger proportion of minority residents might have lower turnout, independent of the election system, our models include a variable that represents the proportion of voting age residents who are nonwhite. In addition to the relative size of the minority population, the specific type of minority is also relevant. Language barriers or citizenship status may mean that Latinos did not turn out at the same rate as other voters. Indeed, studies have found that Latinos turn out at relatively lower rates than whites and African Americans in various elections (Stanley and Niemi 1995, 79; Uhlaner, Cain, and Kiewiet 1989). We include a dummy variable that represents places where Latinos were the largest minority group. ${ }^{15}$ To control for variation in the social composition of these places, we also include a measure of median income. We assume that places with higher median incomes have more residents who have the resources to participate in politics. ${ }^{16}$ Since voters may take less interest in school elections, we also include a dummy variable that distinguishes school board from city and county council elections. Participation might also be lower in larger communities for a number of reasons (see Key 1949; Verba and Nie 1972, 231). Since there are few cases in our analysis with populations over 100,000 , there is an extreme rightward skew in the distribution of this variable. As a result, we found it necessary to use the $\log$ of population as a control.

\section{Cross-Sectional Results}

Table 2 reports the results of a set of cross-sectional estimations of turnout that compare plurality places (control and experimental pre-CV cases) to $\mathrm{CV}$

\footnotetext{
${ }^{15}$ Given the nature of these data, all communities had a sizable minority population. However, no jurisdictions had a large Latino and African-American population simultaneously. The dummy variable thus $=1$ (Latino the largest minority) or $=0$ (African American the largest minority). The majority of elections $(86 \%)$ were contested where Latinos were the predominant minority group.

${ }^{16}$ Likewise, aggregate levels of education could also affect participation. Our measures of income and education, however, are highly correlated $(.80)$, and both are strongly correlated with population (each over .65). To avoid problems of multicollinearity, we omit the measure of education. When education is substituted for income, the substantive results do not change.
} 
TABLE 2

\section{Cross-Sectional Regression Analysis Models of Turnout in Local Elections}

\begin{tabular}{lccc}
\hline & $\begin{array}{c}\text { All } \\
\text { Elections }\end{array}$ & $\begin{array}{c}\text { Matched } \\
\text { by Place }\end{array}$ & $\begin{array}{c}\text { Matched by } \\
\text { Place and Time }\end{array}$ \\
\hline CV Election System & $.052^{* *}$ & $.050^{* *}$ & $.047^{*}$ \\
Minority Population & $(.015)$ & $(.019)$ & $(.028)$ \\
& $-.123^{*}$ & -.098 & -.030 \\
School Board Election & $.075)$ & $(.093)$ & $(.144)$ \\
& $-.028^{*}$ & -.026 & -.007 \\
Latino Community & $.016)$ & $(.021)$ & $(.034)$ \\
& $-.267^{* *}$ & $-.223^{* *}$ & $-.264^{* *}$ \\
Population (logged) & $(.032)$ & $(.039)$ & $(.061)$ \\
& $-.028^{* *}$ & $-.029^{* *}$ & -.023 \\
Median Income & $(.008)$ & $(.010)$ & $(.014)$ \\
& .00002 & .00002 & .00004 \\
Intercept & $(.00002)$ & $(.00003)$ & $.00003)$ \\
& $.692^{* *}$ & $.605^{* *}$ & $.526^{* *}$ \\
$\mathrm{R}^{2}$ (adjusted) & $.080)$ & $(.097)$ & $(.141)$ \\
Number of cases & .449 & .318 & .333 \\
\hline
\end{tabular}

Note: Dependent variable $=$ turnout as a proportion of voting age population. Standard errors in parentheses.

$$
\begin{aligned}
& * *=\text { significant at } p<.01 \text { (one-tail) } \\
& *=\text { significant at } p<.05 \text { (one-tail) }
\end{aligned}
$$

places. The first column reports an OLS estimation using data from all 215 elections - 72 from plurality control places, 74 plurality elections held in experimental places prior to adopting $\mathrm{CV}$, and 69 from experimental places after adopting CV. The second column lists estimates from a set of cases limited to elections from the experimental and control jurisdictions that were matched demographically. ${ }^{17}$ This set includes 63 plurality elections from the control group, 50 plurality elections from places that would end up adopting $\mathrm{CV}$, and $51 \mathrm{CV}$ elections. Cross-sectional comparisons are further refined in the third column with an estimation limited to $\mathrm{CV}$ and plurality elections matched by place as well as time. ${ }^{18}$ This includes $41 \mathrm{CV}$ elections and 41 plurality elections held in similar places at the same time.

The primary variable of interest is the dichotomous measure that indicates whether an election was run under CV. According to each of our cross-

\footnotetext{
${ }^{17}$ This first estimation in Table 2 includes elections from $7 \mathrm{CV}$ places for which we obtained turnout data that lack matching data from plurality jurisdictions.

${ }^{18}$ Since time series for places vary in length, cases are lost when the estimation is limited to when time of election and place are matched.
} 
sectional estimates, elections held under $\mathrm{CV}$ do result in a turnout rate significantly higher than elections run under traditional plurality schemes. The effect of $\mathrm{CV}$ ranges from an increase of 4.7 to 5.2 percentage points, depending on the set of cases being assessed. ${ }^{19}$ The substantive impact of CV elections appears modest when we consider that an increase in national turnout of 5 percentage points would be a relatively small proportionate change in participation. The effect is more impressive, however, when the range of local turnout across these cases is considered. ${ }^{20}$ For a jurisdiction having the mean turnout (19\%), a 5 percentage point increase is, proportionately, a substantial gain.

Several coefficients for control variables are also significant. In the estimation including all elections, there is an independent effect of the type of office being contested. When school board elections are held separately, fewer voters turn out. The log of population is also significant in the first two estimations, with larger jurisdictions having lower turnout. Jurisdictions with Latinos as their primary minority group had lower turnout rates, and the coefficient representing Latino communities is both substantively as well as statistically significant in each estimation. Finally, no estimation demonstrates a significant effect of median income, although the direction of the coefficients suggests wealthier communities have higher participation.

\section{Longitudinal Results}

Thus far we have assumed that plurality and CV places were matched on all relevant variables except election system. With perfect matching, the term for $\mathrm{CV}$ elections would capture the unique effect of election type. Despite care in matching, however, it is possible that the $\mathrm{CV}$ term also captures other factors. Given this limitation, we also estimate longitudinal models of turnout. By looking only at the jurisdictions that experimented with $\mathrm{CV}$, we test for change over time in places that are directly affected by the adoption of CV. Table 3 reports these longitudinal estimates. The CV term represents the intervention of the adoption of $\mathrm{CV}$ and thus reflects the increase in turnout after elections were conducted under CV. The first estimation makes use of turnout data from 143 elections in the experimental places - 74 were plurality contests and 69 were conducted after switching to CV.

Heilig and Mundt (1984) found that the adoption of new SMD systems can be associated with a short-term surge in turnout due to increased electoral competition, but participation may drop after the first election. A similar effect could occur with CV contests. Likewise, mobilization efforts by local groups could be one-time educational affairs that produce an increase in turnout only

\footnotetext{
${ }^{19}$ The size and significance of the effect of election system reported in each estimate in Table 2 remain largely unchanged when dummy variables for year are included in the models.

${ }^{20}$ The dependent variable (turnout) has a mean of .19 and a standard deviation of .14. It ranges from .017 to .682 . The distribution has a noticeable but not severe right tail, with only one case lying further than three standard deviations from the mean.
} 
TABLE 3

Longitudinal Regression Analysis Models of Turnout in Local Elections

\begin{tabular}{lccc}
\hline & $\begin{array}{c}\text { CV Places, } \\
\text { Before \& After } \\
\text { Adopting CV }\end{array}$ & $\begin{array}{c}\text { Cefore \& After, } \\
\text { Excluding First Two } \\
\text { CV Elections }\end{array}$ & $\begin{array}{c}\text { Non-CV } \\
\text { Places Only }\end{array}$ \\
\hline Adoption of CV Election System & $.040^{* *}$ & $.051^{* *}$ & - \\
After 1993 & $(.016)$ & $(.023)$ & -.017 \\
Minority Population & - & - & $(.018)$ \\
Latino & $-.125^{*}$ & -.093 & -.143 \\
& $(.077)$ & $(.098)$ & $(.098)$ \\
School Board Election & $-.247^{* *}$ & $-.248^{* *}$ & $-.251^{* *}$ \\
Population (logged) & $(.039)$ & $(.046)$ & $(.041)$ \\
Median Income & $-.036^{* *}$ & -.027 & -.028 \\
& $(.018)$ & $(.022)$ & $(.019)$ \\
Intercept & $-.050^{* *}$ & $-.047^{* *}$ & $-.020^{*}$ \\
& $(.011)$ & $(.014)$ & $(.009)$ \\
$\mathrm{R}^{2}$ (adjusted) & -.00001 & -.00002 & -.00001 \\
Number of cases & $(.00003)$ & $(.00003)$ & $(.00002)$ \\
& $.889^{* *}$ & $.793^{* *}$ & $.603^{* *}$ \\
& $(.091)$ & $(.112)$ & $(.103)$ \\
& .447 & .446 & .438 \\
& 143 & 98 & 146 \\
\hline
\end{tabular}

Note: Dependent variable $=$ turnout as a proportion of voting age population. Standard errors in parentheses.

$* *=$ significant at $p<.01$ (one-tail)

$*=$ significant at $p<.05$ (one-tail)

after initial $\mathrm{CV}$ elections. The second estimation in Table 3 excludes the first two $\mathrm{CV}$ elections in each jurisdiction to test if increased turnout is sustained after the first two CV contests. We include a third estimation in Table 3 to take full advantage of our research design. Here, we test if turnout has increased over time in places that did not adopt CV. A dummy variable representing all elections contested after 1993 is included to test this. ${ }^{21}$

Most of the coefficients in Table 3 appear similar to the estimates from the cross-sectional analysis (Table 2). Of primary interest here is that the effects of $\mathrm{CV}$ in Table 3 are largely consistent with those reported in Table 2, in the range of 4-5.1 percentage point increase in local turnout after a jurisdiction adopted CV. Overall, the results in Table 3 demonstrate that when a fixed set of jurisdictions in the U.S. switches from plurality to semi-PR election rules, we do

\footnotetext{
${ }^{21}$ We use 1993 as a break point since half of the non-CV elections were conducted after that year.
} 
see a significant, sustained increase in turnout. ${ }^{22}$ Estimates in the second column illustrate that turnout remains 5 percentage points higher than under plurality elections after the second $\mathrm{CV}$ contest. ${ }^{23}$ Moreover, we find that there was no increase in turnout after 1993 in similar places that never adopted $\mathrm{CV}^{24}$

\section{Conclusion}

Our analysis demonstrates that $\mathrm{CV}$ is associated with higher turnout than plurality elections in the U.S. CV thus offers the promise of increased representation of minorities coupled with increased participation. The size of the effect appears to be a modest but noteworthy $4 \%$ to $5 \%$ boost in participation. The jurisdictions examined here adopted $\mathrm{CV}$ because their at-large plurality voting plans created barriers to descriptive representation of minorities. When actions are taken against these plans under the VRA, courts typically accept other plurality systems that produce minority representation (e.g., SMDs). Semiproportionate alternatives to these systems, such as $\mathrm{CV}$, have been found to facilitate minority representation at levels approaching what is found under districting (Brischetto and Engstrom 1997; Cole and Taebel 1992; Pildes and Donoghue 1995). Our results illustrate that the institutional effects of these alternative electoral rules extend beyond just facilitating descriptive representation.

Our quasi-experimental design, controlled case selection, and model estimations demonstrate that the effect of CV on turnout is not an artifact of an analysis that fails to control for place-specific (cultural, social, political, or geographic) factors. All of this suggests quite strongly that some underlying processes associated with $\mathrm{CV}$ act to mobilize more voters than plurality elections do. If political reformers are interested in increasing participation in U.S. elections, these findings could be taken as evidence that PR or semi-PR rules could stimulate greater participation, at least in local elections where the potential problem of low turnout is most severe.

Advocates of electoral reform might find satisfaction in the link we find between institutional rules and participation. Yet the findings could also cast a minor shadow over claims advanced by proponents of PR. If we can generalize from local elections in these mostly small jurisdictions, increased proportional-

\footnotetext{
${ }^{22}$ Models omitting only the first CV contest produce similar results. The size and significance of the effect of election system also remain largely unchanged when dummy variables for year are included in the models.

${ }^{23}$ We also estimated models using data from the CV elections held in places that had at least two or more contests under $\mathrm{CV}$. We replaced the term for election system with a variable representing the number of times a place had a CV election. Results illustrated that the coefficient for election iteration was trivial $(-.009)$, and not at all significant $(\mathrm{p}=.52)$. Thus, the increase in local election turnout demonstrated here does not appear to be the function of some short-lived novelty effect.

${ }^{24}$ We also estimated models for elections in non-CV places using a time-counter, using dummy variables for individual years, and using other years as break points. The substantive results are unchanged in each estimation.
} 
ity in the electoral formula does not appear to be a magic bullet that will resolve problems of low participation in the U.S.: turnout increased, but it remained low. As noted above, there are numerous behavioral, structural, and institutional factors at play here. Election rules, however, are one of many small pieces of the puzzle of low turnout in the U.S.

The results of this study do lend support to cross-national findings that institutional rules affect turnout. We find that even when cultural and social factors are largely controlled, plurality rules continue to demonstrate a deleterious effect on participation. Indeed, we find about the same effect that Blais and Dobrzynska (1998) identify with cross-national data, and we find results close to the 3\%-7\% effect that Ladner and Milner (1999) find PR has on local contests in Switzerland. Given this, and the modest effect that semi-PR election rules have on turnout within the U.S., we suggest that attitudinal, behavioral, and other institutional differences explain much of the participation gap between the U.S. and nations that use PR.

\section{Manuscript submitted 30 August 1999}

Final manuscript received 29 January 2001

\section{References}

Abramson, Paul, and John Aldrich. 1982. "The Decline of Electoral Participation in America." American Political Science Review 76(3): 502-21.

Alford, Robert, and Eugene Lee. 1968. "Voting Turnout in American Cities." American Political Science Review 62(3): 796-813.

Amy, Douglas. 1993. Real Choices, New Voices. New York: Columbia University Press.

$\rightarrow$ Anderson, Chris, and Chris Guillory. 1997. "Political Institutions and Satisfaction with Democracy: A Cross-national Analysis of Consensus and Majoritarian Systems." American Political Science Review 91(1): 66-88.

Banducci, Susan, Todd Donovan, and Jeffrey Karp. 1999. "Proportional Representation and Attitudes about Politics: Results from New Zealand.” Electoral Studies 18(4): 533-555.

Berelson, Bernard, Paul Lazarsfeld, and William McPhee. 1954. Voting. Chicago: University of Chicago Press.

Blais, André, and R. K. Carty. 1990. "Does Proportional Representation Foster Voter Turnout?" European Journal of Politics 18(1): 167-81.

Blais, André, and Agnieszka Dobrzynska. 1998. “Turnout in Electoral Democracies.” European Journal of Political Research 33(2): 239-61.

Brischetto, Robert. 1995. "The Rise of Cumulative Voting." Texas Observer, July 28. Pp. 6-18.

Brischetto, Robert, and Richard Engstrom. 1997. "Cumulative Voting and Latino Representation: Exit Surveys in 15 Texas Communities.” Social Science Quarterly 78(4): 973-91.

$\rightarrow$ Caldeira, Gregory, Samuel Patterson, and Gregory Markko. 1985. "The Mobilization of Voters in Congressional Elections." Journal of Politics 47(2): 490-509.

$\rightarrow$ Canon, David. 1999. "Electoral Systems and the Representation of Minority Interests in Legislatures.” Legislative Studies Quarterly 24(3): 331-86.

$\rightarrow$ Cole, Richard, Delbert Taebel, and Richard Engstrom. 1990. "Cumulative Voting in a Municipal Election: A Note on Voter Reactions and Electoral Consequences." Western Political Quarterly 43(1): 191-99.

Cole, Richard, and Delbert Taebel. 1992. "Cumulative Voting in Local Elections: Lessons from the Alamogordo Experience.” Social Science Quarterly 73(1): 194-201. 
Cox, Gary. 1999. "Electoral Rules and the Calculus of Mobilization." Legislative Studies Quarterly 24(3): 387-420.

Cox, Gary, and Michael Munger. 1989. "Closeness, Expenditure and Turnout in the 1982 U.S. House Elections." American Political Science Review 83(1): 217-31.

Engstrom, Richard, and Charles Barrilleaux. 1991. "Native Americans and Cumulative Voting: The Case of the Sisseton-Wahpeton Sioux." Social Science Quarterly 72(2): 388-93.

Engstrom, Richard, Delbert Taebel, and Richard Cole. 1989. "Cumulative Voting as a Remedy for Minority Vote Dilution: The Case of Alamogordo, New Mexico." Journal of Law and Politics 5(3): 469-97.

Engstrom, Richard, and Michael McDonald. 1981. "The Election of Blacks to City Councils: Clarifying the Impact of Electoral Arrangements on the Seats/Population Relationship." American Political Science Review 75(2): 344-54.

Guinier, Lani. 1994. The Tyranny of the Majority. New York. Free Press.

Heilig, Peggy, and Robert Mundt. 1984. Your Voice at City Hall: The Politics, Procedures, and Policies of District Representation. Albany, NY: SUNY Press.

Jackman, Robert. 1987. "Political Institutions and Voter Turnout in the Industrial Democracies." American Political Science Review 81(2): 405-24.

Jackman, Robert, and Ross Miller. 1995. "Voter Turnout in the Industrial Democracies During the 1980s." Comparative Political Studies 27(4): 467-92.

Jackson, Robert, Robert Brown, and Gerald Wright. 1998. "Registration, Turnout and the Electoral Representatives of U.S. State Electorates." American Politics Quarterly 26(3): 259-89.

Key, V. O. 1949. Southern Politics in Nation and State. New York: Knopf.

Ladner, Andreas, and Henry Milner. 1999. "Do Voters Turn Out More under Proportional than Majoritarian Systems? Evidence from Swiss Communal Elections." Electoral Studies 18(2): 235-50.

Leighley, Jan, and Jonathan Nagler. 1992. "Individual and Systemic Differences on Turnout: Who Votes? 1984." Journal of Politics 54(3): 635-717.

Lijphart, Arend. 1997. "Unequal Participation: Democracy's Unresolved Dilemma." American Political Science Review 91(1): 1-14.

Nagler, Jonathan. 1991. "The Effects of Registration Laws and Education on U.S. Voter Turnout." American Political Science Review 85(4): 1393-1406.

Pildes, Richard, and Kristen Donoghue. 1995. "Cumulative Voting in the United States." The University of Chicago Legal Forum 1995: 241-312.

Piven, Frances Fox, and Richard Cloward. 1988. Why Americans Don't Vote. New York: Pantheon Books.

Polsby, Nelson. 1963. Community Power and Political Theory. New Haven: Yale University Press.

Powell, G. Bingham. 1986. "American Voter Turnout in Comparative Perspective." American Political Science Review 80(1): 17-43.

Rosenstone, Steven, and Raymond Wolfinger. 1978. "The Effects of Registration Laws on Voter Turnout." American Political Science Review 72(1): 22-45.

Rosenstone, Steven, and John Mark Hansen. 1993. Mobilization, Participation and Democracy in America. New York: Macmillan.

Rusk, Jerrold. 1970. "The Effect of the Australian Ballot Reform on Split-Ticket Voting: 18761908." American Political Science Review 64(4): 1220-38.

Stanley, Harold, and Richard Niemi. 1995. Vital Statistics on American Politics. 5th ed. Washington, DC: CQ Press.

Still, Edward. 1984. "Alternatives to Single-Member Districts." In Minority Vote Dilution, ed. C. Davidson. Washington, DC: Howard University Press.

Taebel, Delbert. 1978. "Minority Representation on City Councils: The Impact of Structure on Blacks and Hispanics.” Social Science Quarterly 59(1): 142-52.

Taebel, Delbert, Richard Engstrom, and Richard Cole. 1988. "Alternative Election Systems as Remedies for Minority Vote Dilution." Hamline Journal of Public Law and Policy 11(1): 19-29. 
Teixeira, Ruy. 1992. The Disappearing American Voter. Washington, DC: Brookings Institution Press.

$\rightarrow$ Uhlaner, Carole, Bruce Cain, and D. Roderick Kiewiet. 1989. "Political Participation of Ethnic Minorities in the 1980s." Political Behavior 11(2): 195-231.

Verba, Sidney. 1965. "Conclusion: Comparative Political Culture." In Political Culture and Political Development, ed. Lucian Pye and Sidney Verba. Princeton: Princeton University Press.

Verba, Sidney, and Norman Nie. 1972. Participation in America: Political Democracy and Social Equality. New York: Harper and Row.

Wolfinger, Raymond, and Steven Rosenstone. 1980. Who Votes? New Haven, Yale University Press.

Shaun Bowler is professor of political science, University of California, Riverside. Riverside, CA 92521.

David Brockington is postdoctoral research fellow in political science, Universiteit Twente, Enschede, Netherlands.

Todd Donovan is professor of political science, Western Washington University, Bellingham, WA 98225. 